www.jmscr.igmpublication.org Impact Factor 5.244

Index Copernicus Value: 83.27

ISSN (e)-2347-176x ISSN (p) 2455-0450

crossref DOI:_http://dx.doi.org/10.18535/jmscr/v4i9.20

Journal Of Medical Science And Clinical Research

\title{
A Prospective Study of Alteration in Liver Function Test after Laparoscopic Surgeries
}

Authors

\author{
Dr Krushnakumar G Virda ${ }^{1}$, Dr Amul Bhedi ${ }^{2}$ \\ ${ }^{1,2}$ M.S. (General Surgeon), Department of Surgery \\ Government Medical College Baroda, Vadodara, India \\ Corresponding Author
}

Krushnakumar G. Virda

Address: C/o Dr G.K.Virda, 55-Durveshnagar, "Parth-Krushna" OppSaryu App, Junagadh, Gujarat

Email: krushna.virda@gmail.com, Contact no.:0091-9426622311

\begin{abstract}
Background: Laparoscopy is gaining wide popularity among surgeons in India. There have been no studies in our setting to evaluate the potential deleterious effects of laparoscopic surgery on hepatic function. This study is intended to assess the prevalence, and clinical significance of unexplained disturbances in liver enzymes following laparoscopic surgeries.

Aim and Objectives: To evaluate the Alteration of Liver Function test in patients after Laparoscopic surgeries. And to Compare the Alteration of Liver Function test in Laparoscopic Surgeries with Open Surgeries

Methods: Study conducted with total 60 patients selected by convenient sampling method from those who underwent laparoscopic and open surgery in Medical College Baroda and Sir Sayajirao General Hospital, Vadodara in the period from January 2015 to November 2015. levels of Aspartate Aminotransferase (AST or SGOT), Alanine Aminotransferase (ALT or SGPT), Serum bilirubin and Serum Alkaline Phosphatase were measured preoperatively once and then postoperatively on Day 1, Day 2 and Day 7.

Results: Total 60 patients were studied. Mean difference in liver function test of Laparoscopic group was found between preoperative and postoperative day 1, No significant difference was found on postoperative day 2 and postoperative day 7. Mean difference [Elevation] shown as follow in preoperative and postoperative day 1 was Serum bilirubin: $0.85 \mathrm{mg} / \mathrm{dL}$ to $1.08 \mathrm{mg} / \mathrm{dL}$, SGPT/ALT : $33.7 \mathrm{U} / \mathrm{L}$ to 50.96 U/L, SGOT/AST : $33.23 \mathrm{U} / \mathrm{L}$ to $50.66 \mathrm{U} / \mathrm{L}$ and Alkaline Phosphatase : $70.63 \mathrm{IU} / \mathrm{L}$ to $119.8 \mathrm{IU} / \mathrm{L}$. Mean difference in liver function test of Open group was found between preoperative and postoperative day 1, No significant difference was found on postoperative day 2 and postoperative day 7. Mean difference [Small Degree of Elevation] shown as follow in preoperative and postoperative day 1 [except Serum Bilirubin] was Serum bilirubin: $0.84 \mathrm{mg} / \mathrm{dL}$ to $0.82 \mathrm{mg} / \mathrm{dL}$, SGPT/ALT: $33.67 \mathrm{U} / \mathrm{L}$ to $35.10 \mathrm{U} / \mathrm{L}$, SGOT/AST: $32.46 \mathrm{U} / \mathrm{L}$ to 35.76 U/L and Alkaline Phosphatase: $70.50 \mathrm{IU} / \mathrm{L}$ to $77.23 \mathrm{IU} / \mathrm{L}$.

Conclusion: We observed that elevation in liver function test on postoperative day 1 came back to normal on postoperative day 7 in laparoscopic surgery group. And there was small degree of elevation but within normal range in liver function test in open surgery group which came back to normal on postoperative day 7.

Keywords: Laparoscopic Cholecystectomy, Postoperative Liver Function test.
\end{abstract}




\section{INTRODUCTION}

Minimally invasive surgery, especially laparoscopic surgery, describes an area of surgery that crosses all traditional disciplines and has changed the face of general surgery. The goal of laparoscopic surgery is to perform standard, classical open surgical procedures via the laparoscope to make the operative procedure more patient friendly. Laparoscopy provides access to the peritoneal cavity for diagnosis and also for many surgical interventions which was previously only possible by laparotomy.

The growth of this technique and its applications has developed exponentially, and it currently accounts for a large proportion of all surgical procedures. The main advantages of laparoscopic surgery include the reduction of tissue trauma due to small skin incisions and reduction in adhesion formation. The growing interest in laparoscopy is mostly attributable to cumulative evidence suggesting a reduction in patient morbidity, shortening in hospital stay, and early return to normal activity.

During the last decade many studies have disclosed 'unexplained' changes in postoperative liver function tests in patients undergoing laparoscopic procedures ${ }^{1,2}$. These studies demonstrate that transient elevation of hepatic enzymes could occur after laparoscopic procedures. No causes for this elevation are documented so far. These changes might be attributed to hepatocellular dysfunction secondary to one or combination of $\mathrm{CO} 2$ pneumoperitoneum, diathermy extruding liver, branch of the hepatic artery injured and general anesthesia $^{3}$. CO2 pneumoperitoneum might be one of the main reasons for the change of serum liver enzymes.

The transient elevation of hepatic enzymes showed no apparent clinical implication in most patients who received laparoscopic surgery according to follow-up observations and feedback from these patients. Nevertheless, these results indicate that, if the patient's preoperative liver function was very poor, laparoscopic surgery might not be the optimal choice for treating certain abdominal diseases.

\section{PATIENTS AND METHODS}

Prospective study was conducted to evaluate the effect of laparoscopic and open procedures on liver function. All the patients studied were selected for laparoscopic and open procedures after they underwent routine history taking, physical examination and investigations to exclude pre-existing liver diseases or generalized debility.

Total 60 patients included in the study were selected by convenient sampling method from those who underwent laparoscopic and open surgery in Medical College Baroda and Sir Sayajirao General Hospital, Vadodara. In this study 20 patients [33.33\%] underwent laparoscopic cholecystectomy and 10 patients [16.66\%] underwent laparoscopic appendicectomy while 4 patients [6.66\%] underwent open cholecystectomy and 26 patients [43.33\%] underwent open appendicectomy. The study was conducted over 11 months (January 2015 to November 2015). Data collection period will be approximately 9 months (February 2015 to October 2015).

\section{STATISTICAL METHODS}

Statistical analysis was done by Student Paired t test. The $\mathrm{P}$ value less than 0.05 was considered to be statistically significant.

\section{RESULTS}

This study was conducted on 60 patients admitted in general surgery wards of Sir Sayajirao General Hospital, Vadodara. During evaluation of effect of liver function test before and after 1st postoperative day, 2nd postoperative day and 7th postoperative day of patients who underwent laparoscopic and open surgery. 


\section{JMSCR Vol||04||Issue||09||Page 12421-12433||September}

The data was analysed by using the students paired t test. The P value less than 0.05 was considered to be statistically significant. Result of this study were as follow.

\begin{tabular}{|l|l|}
\hline Laparoscopic Cholecystectomy & 20 \\
\hline Laparoscopic Appendicectomy & 10 \\
\hline Open Cholecystectomy & 4 \\
\hline Open Appendicectomy & 26 \\
\hline
\end{tabular}

\section{$\underline{\text { Statistical Analysis }}$}

\section{LAPAROSCOPIC SURGERY GROUP}

\section{SERUM BILIRUBIN LEVELS:}

Comparison of Mean Serum Bilirubin preoperative and Postoperative day 1, day 2 and day 7 in Laparoscopic surgery group.

\begin{tabular}{|l|c|c|c|c|}
\hline & $\mathrm{N}$ & Mean $(\mathrm{mg} / \mathrm{dL})$ & Std. Deviation & P value \\
\hline PreOp & 30 & 0.85 & 0.15 & \\
\hline Postop day 1 & 30 & 1.08 & 0.38 & 0.0061 \\
\hline Postop day 2 & 30 & 0.86 & 0.14 & 0.7850 \\
\hline Postop day 7 & 30 & 0.86 & 0.14 & 0.7590 \\
\hline
\end{tabular}

\section{COMPARISON OF MEAN SERUM BILIRUBIN VALUE IN PREOPERATIVE AND POSTOPERATIVE 1, 2 AND 7 IN LAPAROSCOPIC SURGERY GROUP}

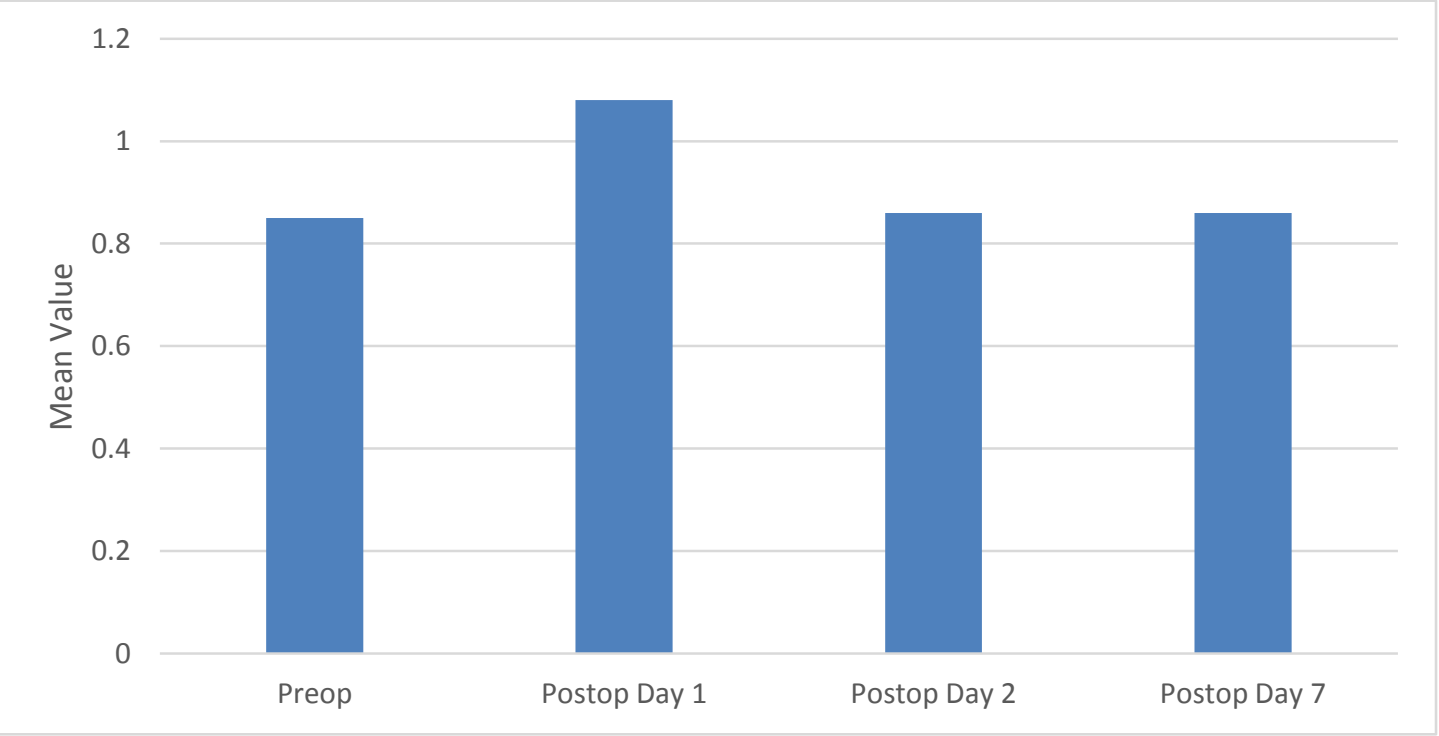

Above table shows serum Bilirubin level preoperatively was $0.85 \pm 0.15 \mathrm{mg} / \mathrm{dL}$ and on postoperative day 1 , 2 and 7 were $1.08 \pm 0.38 \mathrm{mg} / \mathrm{dL}, 0.86 \pm 0.14 \mathrm{mg} / \mathrm{dL}$ and $0.86 \pm 0.14 \mathrm{mg} / \mathrm{dL}$ respectively. There was significant difference of serum Bilirubin level between preoperative and 1st postoperative day $(\mathrm{P}=0.0061$ i.e. $<0.05)$. There was no significant difference between preoperative and 2 nd postoperative day $(\mathrm{P}=0.7850$ i.e. $>0.05)$ and no significant difference between preoperative and 7 th postoperative day $(\mathrm{P}=0.7590$ i.e. $>0.05)$.

Thus it was suggestive of increase in serum bilirubin level in 24 hours postoperatively which came down to near preoperative value within 1 week postoperatively. 


\section{JMSCR Vol||04||Issue||09||Page 12421-12433||September}

\section{SGPT/ALT LEVELS}

Comparison of Mean SGPT/ALT preoperative and Postoperative day 1, day 2 and day7 in Laparoscopic surgery group

\begin{tabular}{|l|c|c|c|c|}
\hline & $\mathrm{N}$ & Mean $(\mathrm{mg} / \mathrm{dL})$ & Std. Deviation & P value \\
\hline PreOp & 30 & 33.70 & 4.28 & \\
\hline Postop day 1 & 30 & 50.96 & 16.07 & $<0.0001$ \\
\hline Postop day 2 & 30 & 38.53 & 7.72 & 0.0014 \\
\hline Postop day 7 & 30 & 33.80 & 4.27 & 0.9257 \\
\hline
\end{tabular}

COMPARISON OF MEAN SGPT/ALT VALUE IN PREOPERATIVE AND POSTOPERATIVE 1, 2 AND 7 IN LAPAROSCOPIC SURGERY GROUP

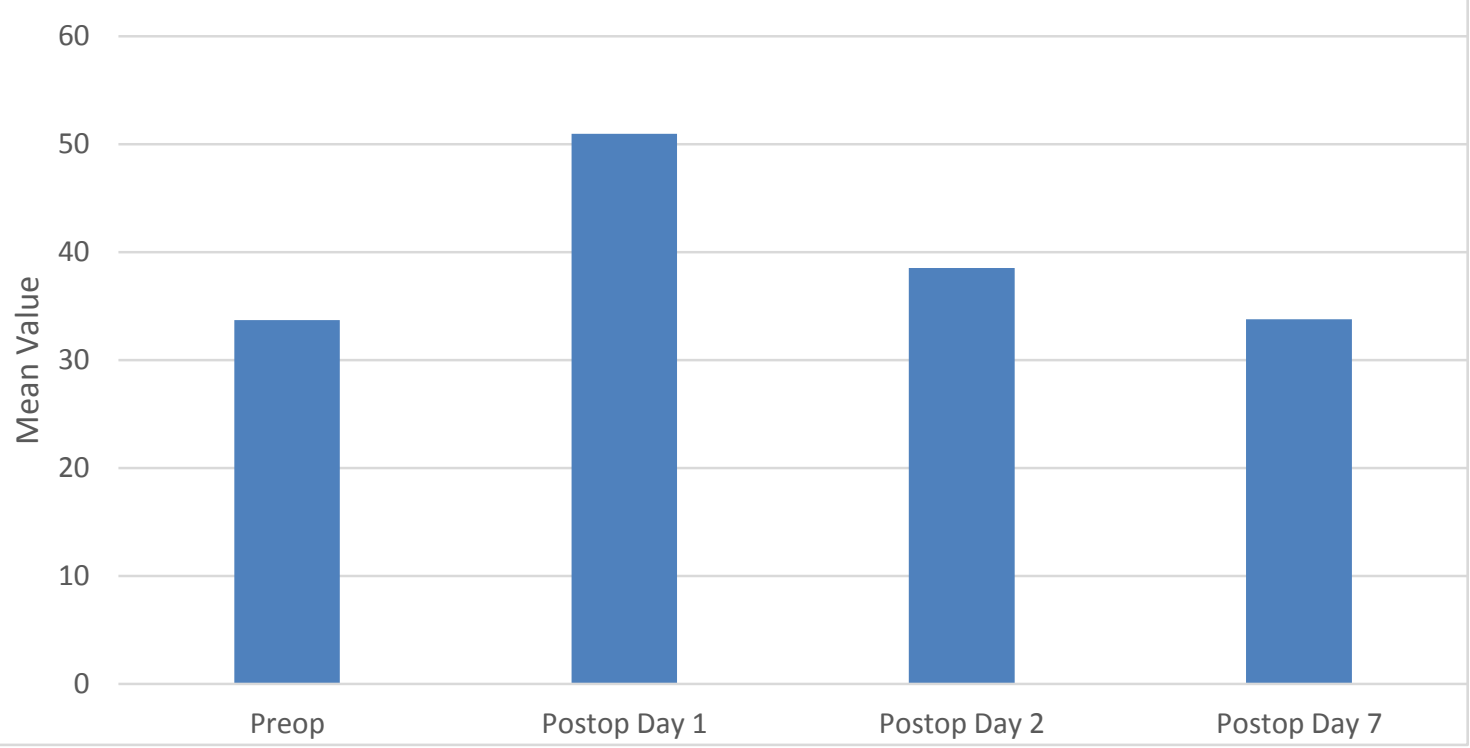

Above table shows ALT/SGPT level preoperatively was $33.70 \pm 4.28 \mathrm{U} / \mathrm{L}$ and on postoperative day 1, 2 and 7 were $50.96 \pm 16.07 \mathrm{U} / \mathrm{L}, 38.53 \pm 7.72 \mathrm{U} / \mathrm{L}$ and $33.80 \pm 4.27 \mathrm{U} / \mathrm{L}$ respectively. There was significant difference of ALT/SGPT level between preoperative and $1^{\text {st }}$ postoperative day $(\mathrm{P}=<0.0001$ i.e. $<0.05)$. There was significant difference between preoperative and $2^{\text {nd }}$ postoperative day $(\mathrm{P}=0.0014$ i.e. $<0.05)$ but no significant difference between preoperative and $7^{\text {th }}$ postoperative day $(\mathrm{P}=0.9257$ i.e. $>0.05)$.

Thus it was suggestive of increase in ALT/SGPT level in 24 to 48 hours postoperatively which came down to near preoperative value within 1 week postoperatively.

\section{SGOT/AST LEVELS}

Comparison of Mean SGOT/AST preoperative and Postoperative day 1, day 2 and day 7 in Laparoscopic surgery group.

\begin{tabular}{|l|c|c|c|c|}
\hline & $\mathrm{N}$ & Mean $(\mathrm{mg} / \mathrm{dL})$ & Std. Deviation & P value \\
\hline PreOp & 30 & 33.23 & 3.79 & \\
\hline Postop day 1 & 30 & 50.66 & 13.28 & $<0.0001$ \\
\hline Postop day 2 & 30 & 38.16 & 9.63 & 0.0130 \\
\hline Postop day 7 & 30 & 32.70 & 4.08 & 0.4939 \\
\hline
\end{tabular}




\section{JMSCR Vol||04||Issue||09||Page 12421-12433||September}

COMPARISON OF MEAN SGOT/AST VALUE IN PREOPERATIVE AND POSTOPERATIVE 1, 2 AND 7 IN LAPAROSCOPIC SURGERY GROUP.

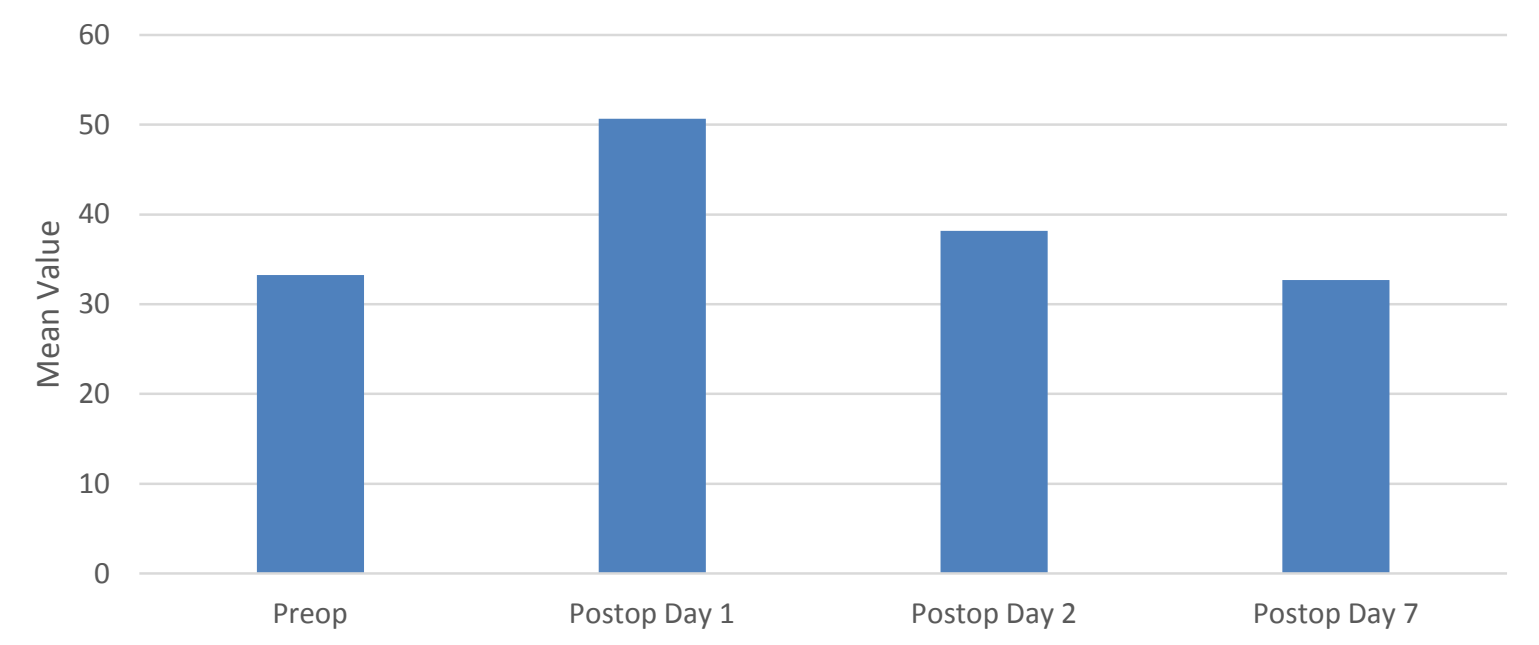

Above table shows AST/SGOT level preoperatively was $33.23 \pm 3.79 \mathrm{U} / \mathrm{L}$ and on postoperative day 1,2 and 7 were $50.66 \pm 13.28 \mathrm{U} / \mathrm{L}, 38.16 \pm 9.63 \mathrm{U} / \mathrm{L}$ and $32.70 \pm 4.08 \mathrm{U} / \mathrm{L}$ respectively. There was significant difference of AST/SGOT level between preoperative and $1^{\text {st }}$ postoperative day $(\mathrm{P}=<0.0001$ i.e. $<0.05)$. There was significant difference between preoperative and $2^{\text {nd }}$ postoperative day $(\mathrm{P}=0.0130$ i.e. $<0.05)$ but no significant difference between preoperative and $7^{\text {th }}$ postoperative day $(\mathrm{P}=0.4939$ i.e. $>0.05)$.

Thus it was suggestive of increase in AST/SGOT level in 24 to 48 hours postoperatively which came down to near preoperative value within 1 week postoperatively.

\section{ALKALINE PHOSPHATASE LEVELS:}

Comparison of Mean Alkaline phosphatase preoperative and Postoperative day 1, day 2 and day 7 in Laparoscopic surgery group.

\begin{tabular}{|l|c|c|c|c|}
\hline & N & Mean $(\mathrm{mg} / \mathrm{dL})$ & Std. Deviation & P value \\
\hline PreOp & 30 & 70.63 & 16.25 & \\
\hline Postop day 1 & 30 & 119.80 & 27.48 & $<0.0001$ \\
\hline Postop day 2 & 30 & 68.03 & 15.07 & 0.5411 \\
\hline Postop day 7 & 30 & 72.50 & 18.79 & 0.7159 \\
\hline
\end{tabular}

COMPARISON OF MEAN S.ALKALINE PHOSPHATASE VALUE IN PREOPERATIVE AND POSTOPERATIVE 1, 2 AND 7 IN LAPAROSCOPIC SURGERY GROUP

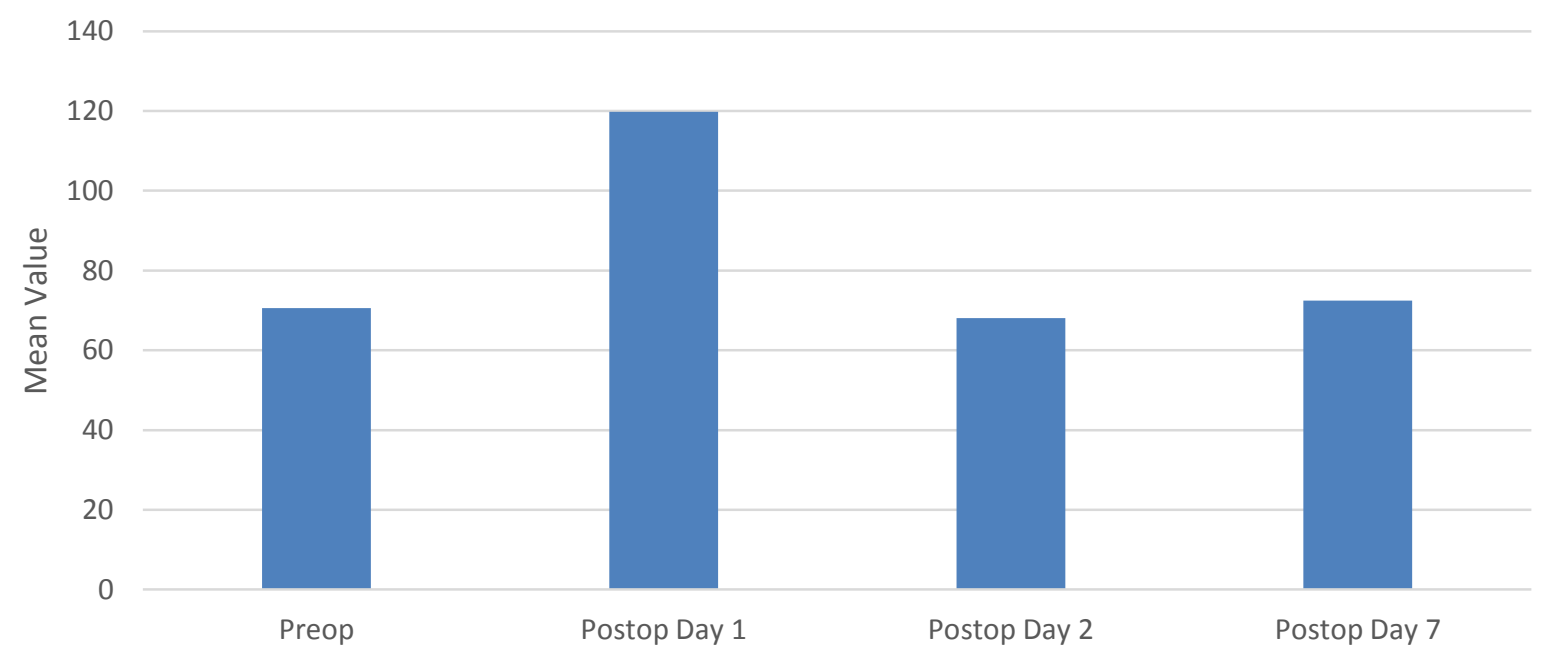




\section{JMSCR Vol||04||Issue||09||Page 12421-12433||September}

Above table shows Alkaline Phosphatase level preoperatively was $70.63 \pm 16.25 \mathrm{IU} / \mathrm{L}$ and on postoperative day 1,2 and 7 were $119.80 \pm 27.48 \mathrm{IU} / \mathrm{L}, 68.03 \pm 15.07 \mathrm{IU} / \mathrm{L}$ and $72.50 \pm 18.79 \mathrm{IU} / \mathrm{L}$ respectively. There was significant difference of Alkaline Phosphatase level between preoperative and $1^{\text {st }}$ postoperative day $(\mathrm{P}=$ $<0.0001$ i.e. $<0.05)$. There was no significant difference between preoperative and $2^{\text {nd }}$ postoperative day $(\mathrm{P}=$ 0.5411 i.e. $>0.05)$ and no significant difference between preoperative and $7^{\text {th }}$ postoperative day $(\mathrm{P}=0.7159$ i.e. $>0.05)$.

Thus it was suggestive of increase in Alkaline Phosphatase level in 24 hours postoperatively which came down to near preoperative value within 1 week postoperatively.

\section{COMPARISION OF LAPAROSCOPIC AND OPEN SURGICAL GROUP SERUM BILIRUBIN LEVELS:}

Comparison of Mean Serum Bilirubin preoperative and Postoperative 1, 2 and 7 in Laparoscopic and Open surgical group.

\begin{tabular}{|l|c|c|c|}
\hline & Laparoscopic surgery group & Open surgery group & P value \\
\hline Preoperative & 0.85 & 0.84 & 0.7510 \\
\hline Post op day 1 & 1.08 & 0.82 & 0.0007 \\
\hline Post op day 2 & 0.86 & 0.85 & 0.7295 \\
\hline Post op day 7 & 0.86 & 0.84 & 0.6014 \\
\hline
\end{tabular}

Comparison of Mean Serum Bilirubin preoperative and Postoperative 1, 2 and 7 in Laparoscopic and Open surgical group.

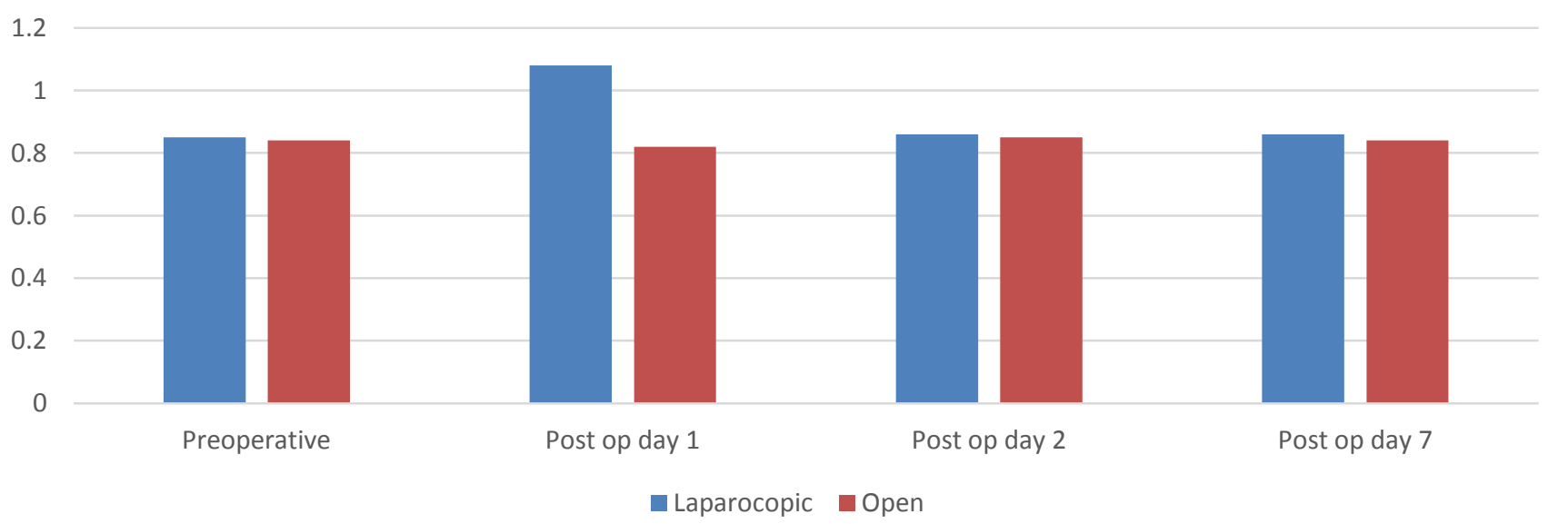

Above table shows Serum Bilirubin level comparison between laparoscopic and open surgical group preoperatively was $0.85 \mathrm{mg} / \mathrm{dL}$ and $0.85 \mathrm{mg} / \mathrm{dL}$, postoperative day 1 was $1.08 \mathrm{mg} / \mathrm{dL}$ and $0.82 \mathrm{mg} / \mathrm{dL}$, postoperative day 2 was $0.86 \mathrm{mg} / \mathrm{dL}$ and $0.85 \mathrm{mg} / \mathrm{dL}$ and postoperative day 7 was $0.86 \mathrm{mg} / \mathrm{dL}$ and 0.84 $\mathrm{mg} / \mathrm{dL}$. There was significant difference between preoperative and postoperative day $1(\mathrm{P}=0.0007$ i.e. $<0.05)$. While there was no significant difference in preoperative $(\mathrm{P}=0.7510$ i.e. $>0.05)$, postoperative day 2 $(\mathrm{P}=0.7295$ i.e. $>0.05)$ and postoperative day $7(\mathrm{P}=0.6014$ i.e. $>0.05)$.

\section{SGOT/AST LEVELS:}

Comparison of Mean SGOT/AST preoperative and Postoperative 1, 2 and 7 in Laparoscopic and Open surgical group

\begin{tabular}{|l|l|l|l|}
\hline & Laparoscopic surgery group & Open surgery group & P value \\
\hline Preoperative & 33.23 & 32.46 & 0.4408 \\
\hline Post op day 1 & 50.66 & 35.76 & $<0.0001$ \\
\hline Post op day 2 & 38.16 & 37.40 & 0.7262 \\
\hline Post op day 7 & 32.70 & 33.13 & 0.6776 \\
\hline
\end{tabular}


Comparison of Mean SGOT/AST preoperative and Postoperative 1, 2 and 7 in Laparoscopic and Open surgical group.

60

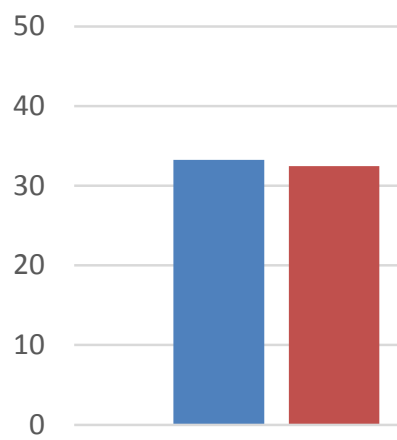

Preoperative

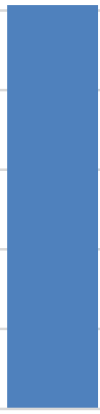

Post op day 1

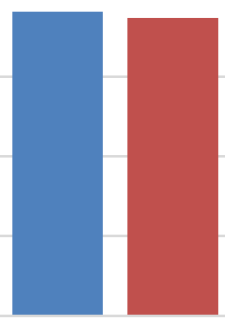

Post op day 2

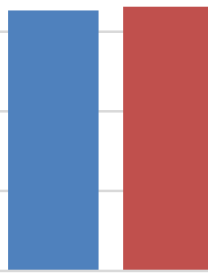

Post op day 7

- Laparocopic mopen

Above table shows SGOT/AST level comparison between laparoscopic and open surgical group preoperatively was $33.23 \mathrm{U} / \mathrm{L}$ and $32.46 \mathrm{U} / \mathrm{L}$, postoperative day 1 was $50.66 \mathrm{U} / \mathrm{L}$ and $35.76 \mathrm{U} / \mathrm{L}$, postoperative day 2 was $38.16 \mathrm{U} / \mathrm{L}$ and $37.40 \mathrm{U} / \mathrm{L}$ and postoperative day 7 was $32.70 \mathrm{U} / \mathrm{L}$ and 33.13 U/L. There was significant difference between preoperative and postoperative day $1(\mathrm{P}=<0.0001$ i.e. $<0.05)$. While there was no significant difference in preoperative $(\mathrm{P}=0.4408$ i.e. $>0.05)$, postoperative day $2(\mathrm{P}=$ 0.7262 i.e. $>0.05)$ and postoperative day $7(\mathrm{P}=0.6776$ i.e. $>0.05)$.

\section{SGPT/ALT LEVELS:}

Comparison of Mean SGPT/ALT preoperative and Postoperative 1, 2 and 7 in Laparoscopic and Open surgical group.

\begin{tabular}{|l|l|l|l|}
\hline & Laparoscopic surgery group & Open surgery group & P value \\
\hline Preoperative & 33.70 & 33.67 & 0.9764 \\
\hline Post op day 1 & 50.96 & 35.10 & $<0.0001$ \\
\hline Post op day 2 & 38.53 & 37.67 & 0.6950 \\
\hline Post op day 7 & 33.80 & 33.97 & 0.8861 \\
\hline
\end{tabular}

Comparison of Mean SGPT/ALT preoperative and Postoperative 1, 2 and 7 in Laparoscopic and Open surgical group.

60

50

40

30

20

10

0

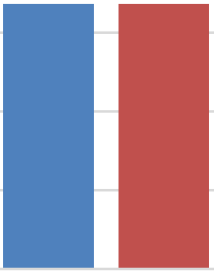

Preoperative

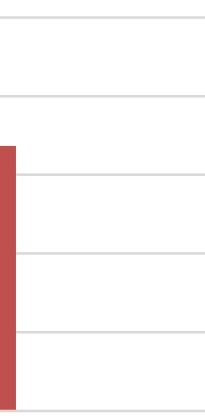

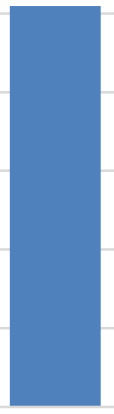

Post op day 1

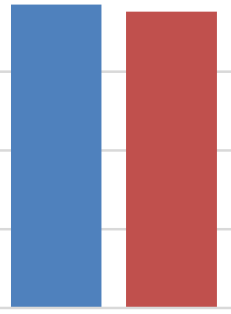

Post op day 2

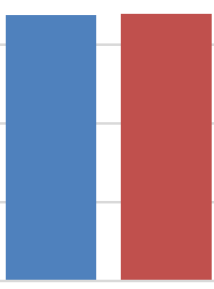

Post op day 7

- Laparocopic m Open 


\section{JMSCR Vol||04||Issue||09||Page 12421-12433||September}

Above table shows SGPT/ALT level comparison between laparoscopic and open surgical group preoperatively was $33.70 \mathrm{U} / \mathrm{L}$ and $33.67 \mathrm{U} / \mathrm{L}$, postoperative day 1 was $50.96 \mathrm{U} / \mathrm{L}$ and $35.10 \mathrm{U} / \mathrm{L}$, postoperative day 2 was $38.53 \mathrm{U} / \mathrm{L}$ and $37.67 \mathrm{U} / \mathrm{L}$ and postoperative day 7 was $33.80 \mathrm{U} / \mathrm{L}$ and 33.97 U/L. There was significant difference between preoperative and postoperative day $1(\mathrm{P}=<0.0001$ i.e. $<0.05)$. While there was no significant difference in preoperative $(\mathrm{P}=0.9764$ i.e. $>0.05)$, postoperative day $2(\mathrm{P}=$ 0.6950 i.e. $>0.05)$ and postoperative day $7(\mathrm{P}=0.8861$ i.e. $>0.05)$.

\section{ALKALINE PHOSPHATASE LEVELS:}

Comparison of Mean Alkaline Phosphatase preoperative and Postoperative 1, 2 and 7 in Laparoscopic and Open surgical group.

\begin{tabular}{|l|l|l|l|}
\hline & Laparoscopic surgery group & Open surgery group & P value \\
\hline Preoperative & 70.63 & 70.50 & 0.9752 \\
\hline Post op day 1 & 119.80 & 77.23 & $<0.0001$ \\
\hline Post op day 2 & 68.03 & 70.96 & 0.4407 \\
\hline Post op day 7 & 72.50 & 68.00 & 0.3079 \\
\hline
\end{tabular}

Comparison of Mean Alkaline Phosphatase preoperative and Postoperative 1, 2 and 7 in Laparoscopic and Open surgical group.

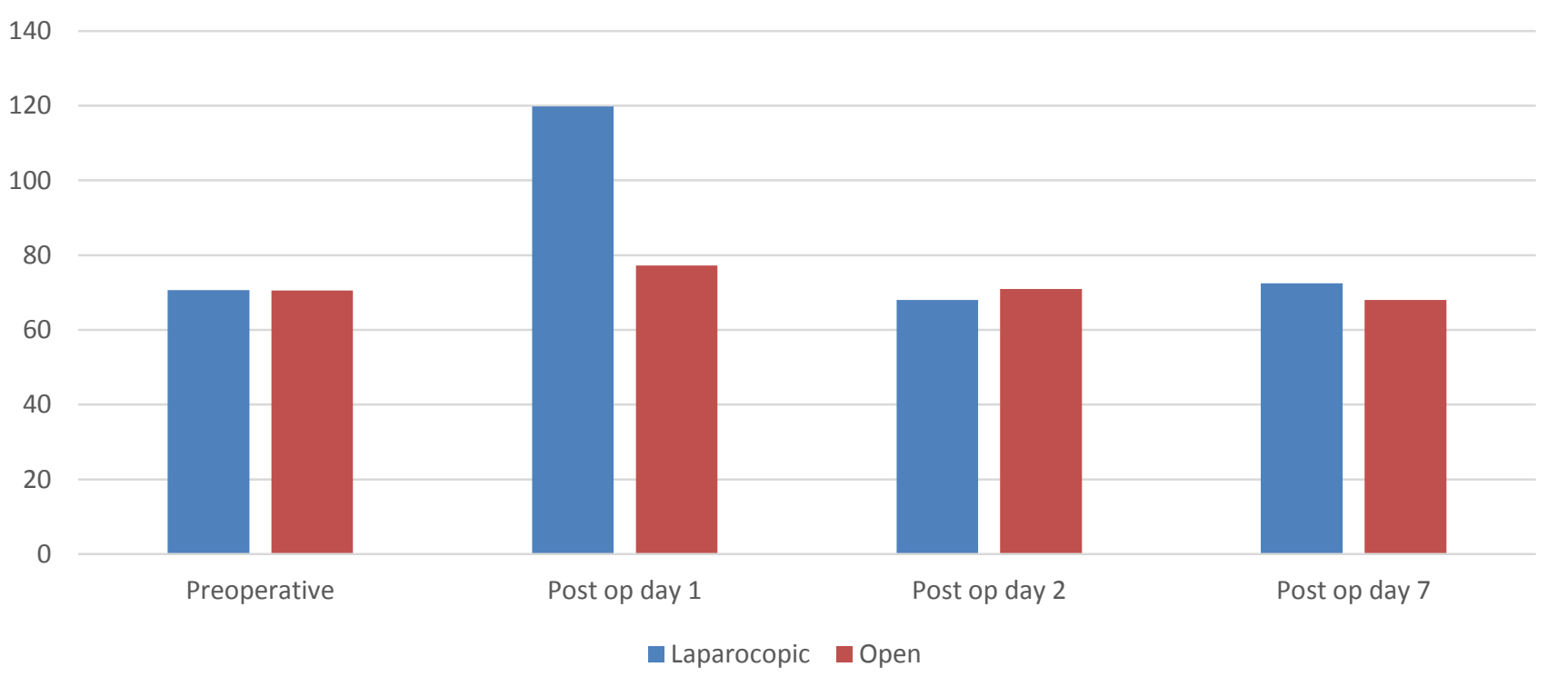

Above table shows Alkaline phosphatase level comparison between laparoscopic and open surgical group preoperatively was $70.63 \mathrm{IU} / \mathrm{L}$ and $70.50 \mathrm{IU} / \mathrm{L}$, postoperative day 1 was $119.80 \mathrm{IU} / \mathrm{L}$ and $77.23 \mathrm{IU} / \mathrm{L}$, postoperative day 2 was $68.03 \mathrm{IU} / \mathrm{L}$ and $70.96 \mathrm{IU} / \mathrm{L}$ and postoperative day 7 was $72.50 \mathrm{IU} / \mathrm{L}$ and 68.00 IU/L. There was significant difference between preoperative and postoperative day $1(\mathrm{P}=<0.0001$ i.e. $<0.05)$. While there was no significant difference in preoperative $(\mathrm{P}=0.9752$ i.e. $>0.05)$, postoperative day 2 $(\mathrm{P}=0.4407$ i.e. $>0.05)$ and postoperative day $7(\mathrm{P}=0.3079$ i.e. $>0.05)$.

\section{DISCUSSION}

Laparoscopic procedures has rapidly emerged as an established method for treatment of many common surgical diseases. The growing interest in laparoscopy is mostly attributable to cumulative evidence suggesting a reduction in patient morbidity, shortening of hospital stay and early return to normal activity. During the last decade many studies have disclosed unexplained changes in postoperative liver function in patients undergoing laparoscopic procedures $\mathrm{CO}_{2}$ pneumoperitoneum might be one of the main reasons for 


\section{JMSCR Vol||04||Issue||09||Page 12421-12433||September}

the change of serum liver enzymes, as this is the only main difference laparoscopic surgeries had when compared with open surgeries. There have been no studies in our setting in India to evaluate the potential deleterious effects of laparoscopic surgery on hepatic function. This study was therefore intended to assess the presence of clinical significance of unexplained disturbances in liver enzymes following laparoscopic surgeries.

In present study 60 patients who constituted the study population, 30 were male patients and 30 were female. All the patients were between 7 and 80 years of age. Majority of the patients were between $20-40$ years age group (i.e. 28 patients).

Patients who underwent various types of laparoscopic \& open surgeries [Cholecystectomy or Appendicectomy] were included in the study. 30 patients were operated for acute or subacute appendicitis. They all underwent either laparoscopic or open appendicectomy. Rest 30 patients were operated for cholelithiasis. They all underwent either laparoscopic or open cholecystectomy.

In all patients the levels of serum bilirubin, serum AST, serum ALT and serum Alkaline phosphatase was checked preoperatively once and post operatively on day 1 , day 2 and day 7 .

\section{Comparison of Mean ALT/SGPT level of various studies for laparoscopic surgery group.}

\begin{tabular}{|l|l|l|l|}
\hline & Pre op & Postop day 1 & Postop day 7 \\
\hline Halvey A et al $^{2}$ & $13.70 \pm 4.80$ & $30.00 \pm 46.50$ & - \\
\hline Tan et al $^{3}$ & $23.30 \pm 11.60$ & $38.80 \pm 15.20$ & $25.10 \pm 14.30$ \\
\hline Güven and Oral et al $^{6}$ & $21.55 \pm 8.92$ & $60.30 \pm 32.17$ & - \\
\hline Ahmad NZ et al $^{7}$ & $28.03 \pm 14.37$ & $67.10 \pm 66.33$ & - \\
\hline Our Study & $33.70 \pm 4.28$ & $50.96 \pm 16.07$ & $33.80 \pm 4.27$ \\
\hline
\end{tabular}

Halvey A et al $^{2}$ stated that the mean level of serum ALT/SGPT preoperatively was $13.70 \pm 4.80 \mathrm{U} / \mathrm{L}$ and postoperatively day 1 was $30.00 \pm 46.50 \mathrm{U} / \mathrm{L}$ with $\mathrm{p}$ value of $<0.005$ i.e. $<0.05$. So author found statistical significant difference.

Tan A et al ${ }^{3}$ stated that the mean level of serum ALT/SGPT preoperatively was $23.30 \pm 11.60 \mathrm{U} / \mathrm{L}$ and postoperatively day 1 was $38.80 \pm 15.20 \mathrm{U} / \mathrm{L}$ with $\mathrm{p}$ value of $<0.05$. So author found statistical significant difference.

Güven and Oral et al ${ }^{6}$ stated that the mean level of serum ALT/SGPT preoperatively was $21.55 \pm 8.92 \mathrm{U} / \mathrm{L}$ and postoperatively day 1 was $60.30 \pm 32.17 \mathrm{U} / \mathrm{L}$ with $\mathrm{p}$ value of $<0.0001$ i.e. $<0.05$. So author found statistical significant difference.

Ahmad NZ et al ${ }^{7}$ stated that the mean level of serum ALT/SGPT preoperatively was $28.03 \pm 14.37 \mathrm{U} / \mathrm{L}$ and postoperatively day 1 was $67.10 \pm 66.33 \mathrm{U} / \mathrm{L}$ with $\mathrm{p}$ value of $<0.05$. So author found statistical significant difference.

In present study there was a significant rise in the serum ALT/SGPT levels in the immediate postoperative period when compared to the preoperative values with $\mathrm{p}$ value $<0.0001$ i.e. $<0.05$, which came down to near preoperative values with in a weeks' time in our study also having mean level of serum ALT/SGPT preoperatively was $33.70 \pm 4.28 \mathrm{U} / \mathrm{L}$. postoperatively day 1 , day 2 and day 7 the levels were $50.96 \pm 16.07$ $\mathrm{U} / \mathrm{L}, 38.53 \pm 7.72 \mathrm{U} / \mathrm{L}$ and $33.80 \pm 4.27 \mathrm{U} / \mathrm{L}$ respectively. 


\section{JMSCR Vol||04||Issue||09||Page 12421-12433||September}

Comparison of Mean AST/SGOT level of various studies for laparoscopic surgery group.

\begin{tabular}{|l|c|c|c|}
\hline & Pre op & Postop day 1 & Postop day 7 \\
\hline Halvey A et al $^{2}$ & $17.30 \pm 4.0$ & $30.90 \pm 50.80$ & - \\
\hline Tan et al $^{3}$ & $28.40 \pm 20.2$ & $41.50 \pm 24.70$ & $29.10 \pm 18.70$ \\
\hline Güven and Oral et al $^{6}$ & $22.76 \pm 6.44$ & $61.72 \pm 28.13$ & - \\
\hline Ahmad NZ et al $^{7}$ & $25.39 \pm 9.68$ & $58.41 \pm 54.04$ & - \\
\hline Our Study & $33.23 \pm 3.79$ & $50.66 \pm 13.28$ & $32.70 \pm 4.08$ \\
\hline
\end{tabular}

Halvey A et al $^{2}$ stated that the mean level of serum AST/SGOT preoperatively was $17.30 \pm 4.0 \mathrm{U} / \mathrm{L}$ and postoperatively day 1 was $30.90 \pm 50.80 \mathrm{U} / \mathrm{L}$ with $\mathrm{p}$ value of $<0.05$. So author found statistical significant difference.

Tan A et al ${ }^{3}$ stated that the mean level of serum AST/SGOT preoperatively was $28.40 \pm 20.2 \mathrm{U} / \mathrm{L}$ and postoperatively day 1 was $41.50 \pm 24.70 \mathrm{U} / \mathrm{L}$ with $\mathrm{p}$ value of $<0.05$. So author found statistical significant difference.

Güven and Oral et al ${ }^{6}$ stated that the mean level of serum AST/SGOT preoperatively was $22.76 \pm 6.44 \mathrm{U} / \mathrm{L}$ and postoperatively day 1 was $61.72 \pm 28.13 \mathrm{U} / \mathrm{L}$ with $\mathrm{p}$ value of $<0.0001$ i.e. $<0.05$. So author found statistical significant difference.

Ahmad NZ et al ${ }^{7}$ stated that the mean level of serum AST/SGOT preoperatively was $25.39 \pm 9.68 \mathrm{U} / \mathrm{L}$ and postoperatively day 1 was $58.41 \pm 54.04 \mathrm{U} / \mathrm{L}$ with $\mathrm{p}$ value of $<0.05$. So author found statistical significant difference.

In present study there was a significant rise in the serum AST/SGOT levels in the immediate postoperative period when compared to the preoperative values with $\mathrm{p}$ value of $<0.0001$ i.e. $<0.05$, which came down to near preoperative values with in a weeks' time in our study also having mean level of serum AST/SGOT preoperatively was $33.23 \pm 3.79 \mathrm{U} / \mathrm{L}$, postoperatively day 1 , day 2 and day 7 the levels were $50.66 \pm 13.28$ $\mathrm{U} / \mathrm{L}, 38.16 \pm 9.63 \mathrm{U} / \mathrm{L}$ and $32.70 \pm 4.08 \mathrm{U} / \mathrm{L}$ respectively.

Comparison of Mean Alkaline Phosphatase level of various studies for laparoscopic surgery group.

\begin{tabular}{|l|c|c|c|}
\hline & Pre op & Postop day 1 & Postop day 7 \\
\hline Halvey A et al $^{2}$ & $105.14 \pm 33$ & $111.11 \pm 40$ & - \\
\hline Güven and Oral et al $^{6}$ & $66.42 \pm 19.40$ & $68.37 \pm 18.28$ & - \\
\hline Ahmad NZ et al $^{7}$ & $83.93 \pm 23.90$ & $82.19 \pm 33.87$ & $72.50 \pm 18.79$ \\
\hline Our Study & $70.63 \pm 16.25$ & $119.80 \pm 27.48$ & - \\
\hline
\end{tabular}

Halvey A et al ${ }^{2}$ stated that the mean level of Alkaline phosphatase preoperatively was $105.14 \pm 33 \mathrm{IU} / \mathrm{L}$ and postoperatively day 1 was $111.11 \pm 40 \mathrm{IU} / \mathrm{L}$ with $\mathrm{p}$ value of $<0.05$. So author found statistical significant difference.

Güven and Oral et al ${ }^{6}$ stated that the mean level of alkaline phosphatase preoperatively was $66.42 \pm 19.40$ IU/L and postoperatively day 1 was $68.37 \pm 18.28 \mathrm{IU} / \mathrm{L}$ with $\mathrm{p}$ value of 0.131 i.e. $>0.05$. So author found statistical no significant difference. 
Ahmad NZ et al ${ }^{7}$ stated that the mean level of alkaline phosphatase preoperatively was $83.93 \pm 23.90$ IU/L and postoperatively day 1 was $82.19 \pm 33.87$ IU/L with $\mathrm{p}$ value of 0.241 i.e. $>0.05$. So author found statistical no significant difference.

In present study there was a significant rise in the alkaline phosphatase levels in the immediate postoperative period when compared to the preoperative values with $\mathrm{p}$ value of $<0.0001$ i.e. $<0.05$, which came down to near preoperative values with in a weeks' time in our study also having mean level of alkaline phosphatase preoperatively was $70.63 \pm 16.25 \mathrm{IU} / \mathrm{L}$. postoperatively day 1 , day 2 and day 7 the levels were $119.80 \pm$ $27.48 \mathrm{IU} / \mathrm{L}, 68.03 \pm 15.07 \mathrm{IU} / \mathrm{L}$ and $72.50 \pm 18.79 \mathrm{IU} / \mathrm{L}$ respectively.

In present study laparoscopic surgery group in details, the mean level of S.bilirubin preoperatively was 0.85 $\pm 0.15 \mathrm{mg} / \mathrm{dL}$. Postoperatively on day 1 , day 2 and day 7 the levels were $1.08 \pm 0.38 \mathrm{mg} / \mathrm{dL}, 0.86 \pm$ $0.14 \mathrm{mg} / \mathrm{dL}$ and $0.86 \pm 0.14 \mathrm{mg} / \mathrm{dL}$ respectively. Thus it was found that there was a significant rise in the serum bilirubin levels in the immediate postoperative period with $p$ value of 0.0061 i.e. $<0.05$ which came down to near preoperative values within 1 week postoperatively.

\section{Comparison of Mean ALT/SGPT level of various studies for open surgery group.}

\begin{tabular}{|l|l|l|}
\hline & Pre op & Postop day 1 \\
\hline Tan A et al 3 & $21.80 \pm 16.70$ & $28.2 \pm 13.70$ \\
\hline Our Study & $33.67 \pm 4.39$ & $35.10 \pm 5.20$ \\
\hline
\end{tabular}

For open surgical group Tan A et al ${ }^{3}$ stated that the mean level of ALT/SGPT preoperatively was $21.80 \pm$ 16.7 U/L and postoperatively day 1 was $28.2 \pm 13.7 \mathrm{U} / \mathrm{L}$ with $\mathrm{p}$ value of $>0.05$. So author found no statistical significant difference and small degree of increase in ALT/SGPT level postoperatively.

In present study there was a small degree of increase in the ALT/SGPT as preoperatively was $33.67 \pm$ 4.39U/L and postoperatively day 1 was $35.10 \pm 5.20 \mathrm{U} / \mathrm{L}$ in the postoperative period when compared to the preoperative values with $\mathrm{p}$ value of 0.2515 i.e. $>0.05$. But the increase was in normal range.

\section{Comparison of Mean AST/SGOT level of various studies for open surgery group.}

\begin{tabular}{|l|l|l|}
\hline & Pre op & Postop day 1 \\
\hline Tan A et al 3 & $25.20 \pm 17.60$ & $31.80 \pm 22.10$ \\
\hline Our Study & $32.46 \pm 3.85$ & $35.76 \pm 4.32$ \\
\hline
\end{tabular}

For open surgical group Tan A et al $^{3}$ stated that the mean level of serum AST/SGOT preoperatively was $25.20 \pm 17.60 \mathrm{U} / \mathrm{L}$ and postoperatively day 1 was $31.80 \pm 22.10 \mathrm{U} / \mathrm{L}$ with $\mathrm{p}$ value of $<0.05$. So author found statistical significant difference and small degree of increase in AST/SGOT level postoperatively.

In present study there was a small degree of increase in the AST/SGOT as preoperatively was $32.46 \pm 3.85$ $\mathrm{U} / \mathrm{L}$ and postoperatively day 1 was $35.76 \pm 4.32 \mathrm{U} / \mathrm{L}$ in the postoperative period when compared to the preoperative values with $\mathrm{p}$ value of 0.0044 i.e. $<0.05$. But the increase was in normal range.

In present study Open surgery group found no rise in serum bilirubin levels in postoperative day 1 , day 2 and day 7 either it was cholecystectomy or appendicectomy. As Serum Bilirubin level preoperatively was $0.84 \pm 0.15 \mathrm{mg} / \mathrm{dL}$ and on postoperative day 1,2 and 7 were $0.82 \pm 0.08 \mathrm{mg} / \mathrm{dL}, 0.85 \pm 0.15 \mathrm{mg} / \mathrm{dL}$ and 0.84 $\pm 0.15 \mathrm{mg} / \mathrm{dL}$ respectively. 
In present study Open surgical group, Alkaline phosphatase was $70.50 \pm 16.79 \mathrm{IU} / \mathrm{L}$ and on postoperative day 1, 2 and 7 were $77.23 \pm 9.29 \mathrm{IU} / \mathrm{L}, 70.96 \pm 14.18 \mathrm{IU} / \mathrm{L}$ and $68.00 \pm 14.85 \mathrm{IU} / \mathrm{L}$ respectively. There was small degree of increase in level of Serum Alkaline Phosphatase in open surgical group postoperatively day 1 and day 2 but within normal range. Which was similar to preoperative at postoperative day 7 .

Comparing laparoscopic surgery with open surgery we found significant rise in serum Bilirubin, SGPT/ALT, SGOT/AST, Alkaline Phosphatase on postoperative day 1. For serum Bilirubin it was 0.85 $\mathrm{mg} / \mathrm{dL}$ to $1.08 \mathrm{mg} / \mathrm{dL}$ and $0.84 \mathrm{mg} / \mathrm{dL}$ to $0.82 \mathrm{mg} / \mathrm{dL}$ in laparoscopic and open surgical group. For SGOT/AST it was $33.23 \mathrm{U} / \mathrm{L}$ to $50.66 \mathrm{U} / \mathrm{L}$ and $32.46 \mathrm{U} / \mathrm{L}$ to $35.76 \mathrm{U} / \mathrm{L}$ in laparoscopic and open surgical group. For SGPT/ALT it was 33.70 U/L to $50.96 \mathrm{U} / \mathrm{L}$ and $33.67 \mathrm{U} / \mathrm{L}$ to $35.10 \mathrm{U} / \mathrm{L}$ in laparoscopic and open surgical group. For Alkaline Phosphatase it was 70.63 IU/L to119.80 IU/L and 70.50 IU/L to 77.23 IU/L in laparoscopic and open surgical group.

There was significant rise in liver function test in postoperative day 1 in laparoscopic surgery group. While in open surgery group there was small degree of rise but in normal range in liver function test on postoperative day 1 . This rise postoperatively returned back to normal as preoperative level by postoperative day 7.

The transient postoperative increases in the serum bilirubin and liver enzyme levels were seen in the study population irrespective of the type of laparoscopic surgery they underwent. In all the patients where there was a transient rise in the enzyme levels, the values returned to near preoperative concentrations within one week after surgery. None of the patients presented with clinical hepatic dysfunction after the surgery according to follow up observations and feedback from these patients.

\section{CONCLUSION}

We observed that elevation in liver function test on postoperative day 1 came back to normal on postoperative day 7 in laparoscopic surgery group. And there was small degree of elevation but within normal range in liver function test in open surgery group which came back to normal on postoperative day 7 . These transient changes might be attributed to hepatocellular dysfunction secondary to one or combination of $\mathrm{CO} 2$ pneumoperitoneum, diathermy on liver and general anaesthesia3.

Based on our findings and other similar studies in the past, $\mathrm{CO} 2$ pneumoperitoneum might be one of the main reasons for this change.

The transient elevation of liver enzymes showed no apparent clinical implication in most patients who received laparoscopic surgery3.

These results however indicate that if the preoperative liver function was very poor, laparoscopic surgery might not be the optimal choice for treating certain abdominal diseases.

\section{REFERENCES}

1. Andrei VE, Schein M et.al."Liver enzymes are commonly elevated following laparoscopic cholecystectomy: is elevated intra-abdominal pressure the cause?” Dig Surg 1998;15(3):256-9.

2. Halvey A, Gold-Deutch R et. al. "Are elevated liver enzymes and bilirubin levels significant after laparoscopic cholecystectomy in the absence of bile duct injury?” Am Surg1995 Apr;221(4):433.

3. Tan M, Xu FF et. al. "Changes in the level of serum liver enzymes after laparoscopic surgery." World J Gastroenterol 2003 Feb 15; 9(1;2):364-367

4. Morino M, Giraudo G “Alterations in hepatic function during laparoscopic surgery. An experimental clinical study." Surg Endosc 1998.

5. Saber AA, Laraja RD et.al. "Changes in liver function tests after laparoscopic cholecystectomy: not so rare, not always ominous.” Am Surg 2000 Jul;66(7) 699-702Jul;12(7):968-721. 


\section{JMSCR Vol||04||Issue||09||Page 12421-12433||September}

6. H.Erhan Güven, Süleyman Oral; "Liver Enzyme Alterations after Laparoscopic Cholecystectomy"; J Gastrointestin Liver Dis December 2007 Vol.16 No 4, 391-394.

7. Ahmad NZ "Routine Testing of Liver Function Before and After Elective Laparoscopic Cholecystectomy". JSLS (2011) Volume 15:65-69.

8. G Marakis, T Pavlidis, K Ballas, S Rafailidis, K Psarras, N Symeonidis, A Triantafyllou, A Sakantamis. "Alterations In Liver Function Tests Following Laparoscopic Cholecystectomy. " The Internet Journal of Surgery. 2005 Volume 8 Number 13. 